\title{
Seasonal variations of major ions in fresh snow at Baishui Glacier No. 1, Yulong Mountain, China
}

\author{
Guofeng Zhu $\cdot$ Tao Pu $\cdot$ Yuanqing He • \\ Peiji Shi $\cdot$ Tao Zhang
}

Received: 9 May 2011/ Accepted: 21 August 2012/Published online: 6 September 2012

(c) The Author(s) 2012. This article is published with open access at Springerlink.com

\begin{abstract}
This study presented a study of seasonal variations of major ion concentrations in fresh snow on Baishui Glacier No. 1, the largest glacier on Yulong Mountain, China. Fresh snow samples at Baishui Glacier No. 1 were collected from November 2008 to October 2009 for chemical data analysis. The results showed that the neutralizing effect of terrestrial source aerosols raised the $\mathrm{pH}$ value of fresh snow. The conductivity of fresh snow was much higher in dry season than that in rainy season. It was evident that the concentration of inorganic ions was generally higher in the dry season than that in rainy season, and the highest values occurred in the pre-monsoon period (April-May). The ions of fresh snow mainly came from terrestrial under the influence of west wind circulation and the Plateau monsoon in dry seasons, and had much complex sources in rainy season under the control of southeast and southwest monsoons. Both wind speed and precipitation had potential effects on ion concentration and composition of fresh snow as well. Moreover, principal component analysis showed that fresh snow ions were mainly from local lithology in dry season and from oceans in rainy season.
\end{abstract}

G. Zhu $(\bowtie) \cdot$ P. Shi

College of Geography and Environment Science of Northwest

Normal University, Lanzhou 730070, China

e-mail: guofeng_zhu@yahoo.cn

T. $\mathrm{Pu} \cdot \mathrm{Y} . \mathrm{He}$

Research School of Arid Environment and Climate Change, Lanzhou University, Lanzhou 730000, China

Y. He - T. Zhang

State Key Laboratory of Cryosphere Sciences, Cold and Arid Regions Environmental and Engineering Research Institute, Chinese Academy of Sciences, Lanzhou 730000, China
Keywords Yulong Mountain - Baishui Glacier No. 1 . Fresh snow · Inorganic ions

\section{Introduction}

Situated along the eastern margin of the Tibetan Plateau, Yulong Mountain covers about $13 \mathrm{~km}$ from west to east and $35 \mathrm{~km}$ from south to north; the peak is 5,596 m. During summer, precipitation in the Yulong Mountain region is caused mainly by moisture transported by the Indian monsoon and/or by local moisture from short distance convective air mass transport, and moisture is transported by the westerly system during winter and spring (October-May) (Stravisi et al. 1998; Thompson et al. 2000a, b). The area has a mean annual temperature of about $-3.7^{\circ} \mathrm{C}$. The annual precipitation is high $(1,000-3,000 \mathrm{~mm})$ and the snowline is at 4,200-5,200 $\mathrm{m}$ a.s.l ( $\mathrm{Li}$ and $\mathrm{Su} 1996)$.

Fresh snow on the glaciers is influenced by monsoons. The markedly different trajectories of the air masses in summer and winter, which are responsible for snow deposition, result in very different snowpack chemistries (Li et al. 2008a, b, 2009). Studies of glacio-chemistry in Yulong Snow Mountain can provide a valuable record of atmospheric circulation ( $\mathrm{He}$ et al. 2001a, b, 2002a, b, 2003; Pang et al. 2007; Thompson et al. 2000a, b). Dating accuracy is essential to the reconstruction of ice core climatic records and primary dating method is the measurement of seasonal variations in chemical species (Thompson et al. 2000a, b). To validate seasonal timing of chemical species, it is necessary to establish input timing. However, due to the severe weather in winter and the difficult logistics encountered in the high regions of the Yulong Mountain, continuous yearly precipitation sampling is difficult to launch. Few studies of snow chemistry on these glaciers have been carried out ( $\mathrm{Li}$ et al. 2008b). 
In this study, fresh snow samples were collected during November 2008 to October 2009 in the Baishui Glacier No. 1 (Fig. 1), which is located on the east slope of Yulong Mountain, with three main aims: (1) to examine seasonal variations of major ion concentrations of fresh snow; (2) to investigate the influences of monsoon and other controlling factors/mechanisms on snow chemistry; (3) to accumulate data for further study on atmospheric environment and environmental records.

\section{Sample collection and analysis}

A total of 36 fresh snow samples were collected on the Baishui Glacier No. 1 on the eastern slope of Yulong Mountain (Fig. 1). The interval from snowing to sampling is less than $24 \mathrm{~h}$ and the snow surface is clean, with elimination of surface snow $2 \mathrm{~cm}$ by stainless steel ice shovel and fresh snow distribute in 3-5 cm were collected (Mayewski 1986; Wake et al. 1993, 1994). Polyethylene gloves and masks were worn at all times during sampling. Rewashed high-density polyethylene containers were used as sample scoops. Samples were kept frozen during transportation and stored in a $-15^{\circ} \mathrm{C}$ coldchamber the State Key Laboratory of Cryospheric Science, Cold and Arid Regions Environment and Engineering Research Institute, Chinese Academy of Sciences. Analysis of duplicate samples in the field and laboratory blanks indicated that sample contamination can be negligible during sample collection, transport, and analytical procedures.

With a PHS-3B electrode the $\mathrm{pH}$ was analyzed, the standard deviation is $< \pm 0.01$; conductivity was analyzed with DDS-308A conductivity meter and the standard deviation is $< \pm 0.1 \mu \mathrm{s} / \mathrm{cm}$; cations $\left(\mathrm{K}^{+}, \mathrm{Na}^{+}, \mathrm{Ca}^{2+}, \mathrm{Mg}^{2+}\right)$ were analyzed with a DX320 ion chromatograph, and anions were analyzed $\left(\mathrm{Cl}^{-}, \mathrm{NO}_{3}{ }^{-}, \mathrm{SO}_{4}{ }^{2-}\right)$ with a $\mathrm{ICS} 1500$ ion chromatograph. The analytical standard deviation is $<5 \%$. The monthly mean of 25 storm events results were shown in Table 1.

The data of precipitation and temperature in Baishui Glacier No. 1 were collected by automatic weather stations

Fig. 1 Baishui Glacier No. 1

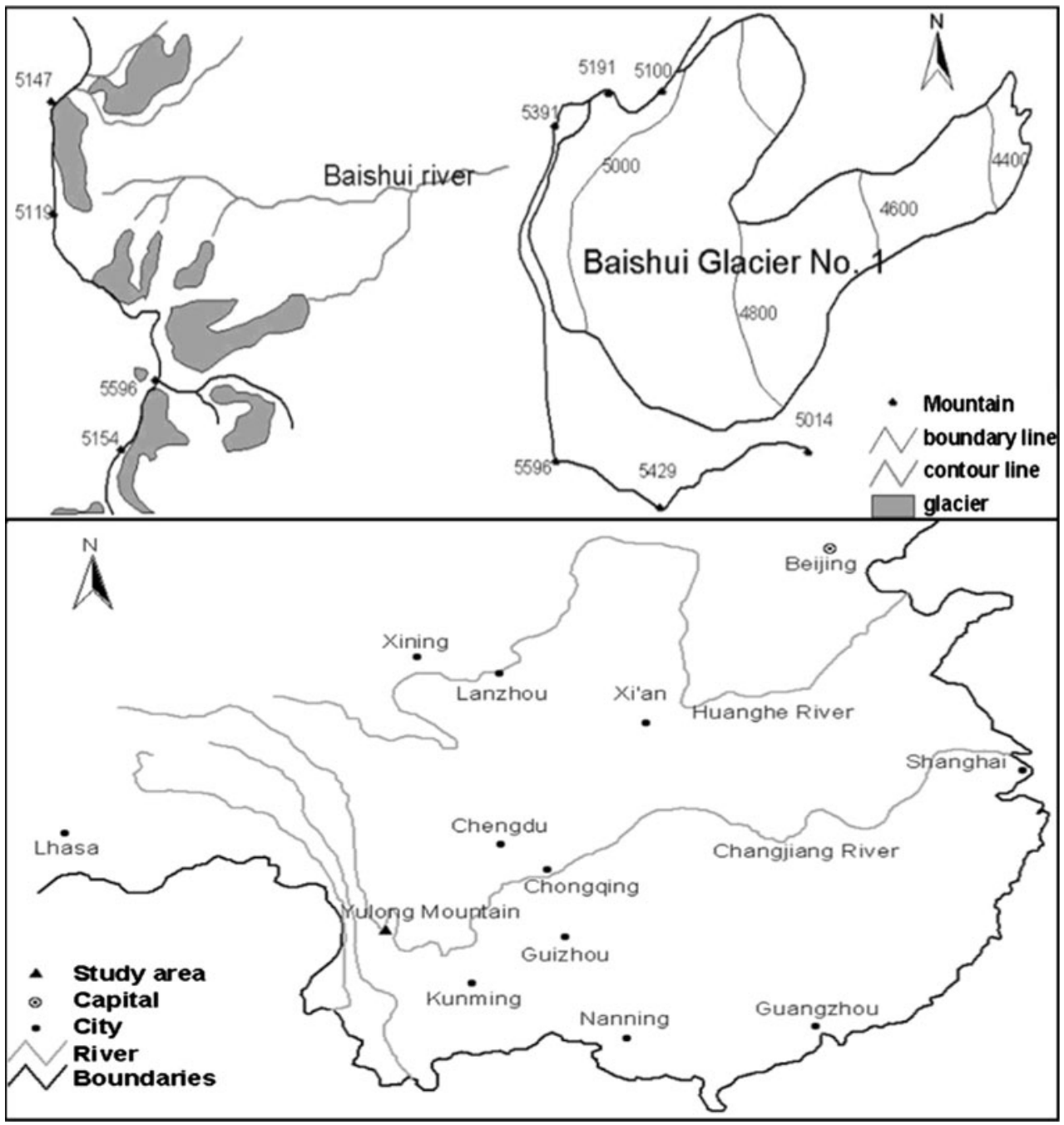


Table 1 The ions concentration of fresh snow in Baishui No. 1 Glacier (unit: $\mu \mathrm{eq} / \mathrm{L}$ )

\begin{tabular}{|c|c|c|c|c|c|c|c|c|c|c|c|c|}
\hline Time & $\mathrm{Cl}^{-}$ & $\mathrm{NO}_{2}^{-}$ & $\mathrm{NO}_{3}^{-}$ & $\mathrm{SO}_{4}{ }^{2-}$ & $\mathrm{Na}^{+}$ & $\mathrm{NH}_{4}^{+}$ & $\mathrm{K}^{+}$ & $\mathrm{Mg}^{2+}$ & $\mathrm{Ca}^{2+}$ & Precipitation & Temperature & $\Sigma$ cat $/ \Sigma$ an \\
\hline 2008-11-18 & 0.9 & 0.0 & 1.9 & 7.6 & 0.8 & 0.2 & 0.6 & 0.2 & 12.9 & 24.1 & -4.0 & 1.4 \\
\hline $2008-12-15$ & 1.5 & 0.1 & 10.3 & 31.0 & 0.4 & 0.4 & 0.7 & 11.0 & 624.2 & 8.5 & -5.4 & 14.9 \\
\hline 2009-01-20 & 2.1 & 0.0 & 16.8 & 24.8 & 0.6 & 0.0 & 0.9 & 11.4 & $1,007.3$ & 4.5 & -7.4 & 23.3 \\
\hline 2009-02-18 & 1.0 & 0.1 & 4.8 & 19.6 & 0.4 & 0.3 & 0.5 & 3.9 & 217.3 & 5.6 & -6.6 & 8.7 \\
\hline 2009-03-16 & 0.9 & 0.1 & 3.7 & 16.7 & 0.3 & 0.3 & 0.4 & 2.7 & 149.6 & 22.7 & -6.1 & 7.2 \\
\hline 2009-04-20 & 4.6 & 0.1 & 42.1 & 270.8 & 1.6 & 7.4 & 4.2 & 3.7 & 117.3 & 35.6 & -1.8 & 0.4 \\
\hline 2009-05-18 & 3.1 & 0.1 & 6.7 & 26.3 & 1.8 & 0.8 & 1.6 & 2.2 & 37.8 & 128.5 & 1.6 & 1.2 \\
\hline 2009-06-18 & 0.6 & 0.1 & 1.8 & 14.0 & 0.0 & 0.2 & 0.3 & 0.4 & 14.4 & 408.2 & 3.8 & 0.9 \\
\hline 2009-07-18 & 0.4 & 0.1 & 1.6 & 12.0 & 0.1 & 0.0 & 0.3 & 2.2 & 44.0 & 452.7 & 5.2 & 3.3 \\
\hline 2009-08-19 & 0.4 & 0.0 & 5.8 & 13.8 & 0.0 & 0.1 & 0.2 & 1.2 & 13.7 & 388.1 & 4.3 & 0.8 \\
\hline 2009-09-20 & 0.5 & 0.0 & 4.6 & 26.2 & 0.0 & 0.6 & 0.5 & 2.8 & 41.7 & 178.3 & 3.4 & 1.5 \\
\hline 2009-10-20 & 1.1 & 0.1 & 22.3 & 84.9 & 0.0 & 0.8 & 0.9 & 18.4 & 493.3 & 133.7 & 0.9 & 4.7 \\
\hline Dry season & 1.8 & 0.1 & 13.3 & 61.7 & 0.7 & 1.4 & 1.2 & 5.5 & 354.8 & 16.8 & -5.2 & 9.3 \\
\hline Rainy season & 1.0 & 0.1 & 7.1 & 29.5 & 0.3 & 0.4 & 0.6 & 4.5 & 107.5 & 281.6 & 3.2 & 2.1 \\
\hline Annual & 1.4 & 0.1 & 10.2 & 45.6 & 0.5 & 0.9 & 0.9 & 5.0 & 231.1 & 149.2 & -1.3 & 5.7 \\
\hline
\end{tabular}

(AWS, Campbell Company) located in 4,300 m. Glacier terminal, glacier balance line and the ice temperature data had been measured by members of State Key Laboratory of Cryosphere Sciences.

\section{Trajectory analyses and sea-salt tracer}

Back-trajectory analysis has been widely applied in the field of atmospheric and glaciological sciences (Kahl et al. 1997; Li et al. 2009; Raben et al. 2000; Theakstone 2008). The Hybrid Single-Particle Lagrangian Integrated Trajectory model, HYSPLIT4 [Air Resources Laboratory, US National Oceanic and Atmospheric Administration (NOAA, http:// www.arl.noaa.gov/ready/hysplit4.html), were used to compute back-trajectories to Baishui No. 1 Glacier $(27.338 \mathrm{~N}$, 100.258E; 4,500-5,500 $\mathrm{m}$ a.s.1.]. The compromise of 5-day back-trajectories with a daily resolution was adopted to simulate the routes of air masses arriving at the sampling site.

\section{Results}

$\mathrm{pH}$ and conductivity

All $\mathrm{pH}$ values of fresh snow collected in Baishui Glacier No. 1 (36 samples) were within the range of 6.27-7.01 (averaging 6.60). The values ranged from 6.41 to 6.82 (averaging 6.59) in rainy season and 6.31 to 6.95 (averaging 6.61) in dry season, which were higher than 5.6, indicating that fresh snow was free of acid pollution from human activities. In addition, the neutralization effects of associated carbonates and bicarbonates were strong.
Research had showed that the buffering of aerosol would be heightened with the concentration of $\mathrm{Ca}^{2+}$ increased (Hu et al. 2005; Zhao et al. 1985; Zhou et al. 2009). The major inorganic ions in fresh snow were $\mathrm{Ca}^{2+}, \mathrm{Mg}^{2+}$, $\mathrm{SO}_{4}{ }^{2-}, \mathrm{NO}_{3}{ }^{-}$and $\mathrm{NH}_{4}{ }^{+}$. Atmospheric mineral particles (including $\mathrm{Ca}^{2+}, \mathrm{Mg}^{2+}$ and other cations) and $\mathrm{NH}_{3}$ had neutralized reaction with $\mathrm{SO}_{4}{ }^{2-}$ and $\mathrm{NO}_{3}{ }^{-}$. The ratio of $\mathrm{Ca}^{2+} /\left(\mathrm{SO}_{4}{ }^{2-}+\mathrm{NO}_{3}{ }^{-}\right)$in fresh snow was 1.99 in rainy season and 8.35 in dry season (Fig. 2), indicating that $\mathrm{Ca}^{2+}$ can neutralize acidic ions effectively.

Conductivity is an important indicator of solution chemical property (Barrie et al. 1985; Hempel et al. 2000; Hammer 1980; Taylor et al. 1993; Wolff et al. 1995). The conductivity of fresh snow was within the range of $4.29-15.41 \mu \mathrm{s} \mathrm{cm}^{-1}$ (averaging $11.56 \mu \mathrm{s} \mathrm{cm}^{-1}$ ) in dry season and $1.52-12.2 \mu \mathrm{s} \mathrm{cm}^{-1}\left(4.56 \mu \mathrm{sm}^{-1}\right)$ in rainy season. The values were much higher in dry season than in rainy season. The conductivity increased while the precipitation decreased (Fig. 2). Relatively high impurity contents in aerosol have been found in dry season, little precipitation led to high impurity contents in precipitation and resulted in the higher values of conductivity in fresh snow. The conductivity of snow collected from June to September was low with minor fluctuation (Fig. 2), which indicated that during the period the surface fresh snow on Baishui Glacier No. 1 was relatively clean and could be seen as the background level of summer precipitation in Yulong Mountain area.

Major ions and ion balance

In dry season, $\mathrm{SO}_{4}{ }^{2-}$ ranked first in the anion concentration with a mean value of $61.7 \mu \mathrm{eq} / \mathrm{L}$, followed by $\mathrm{NO}_{3}{ }^{-}$with a 

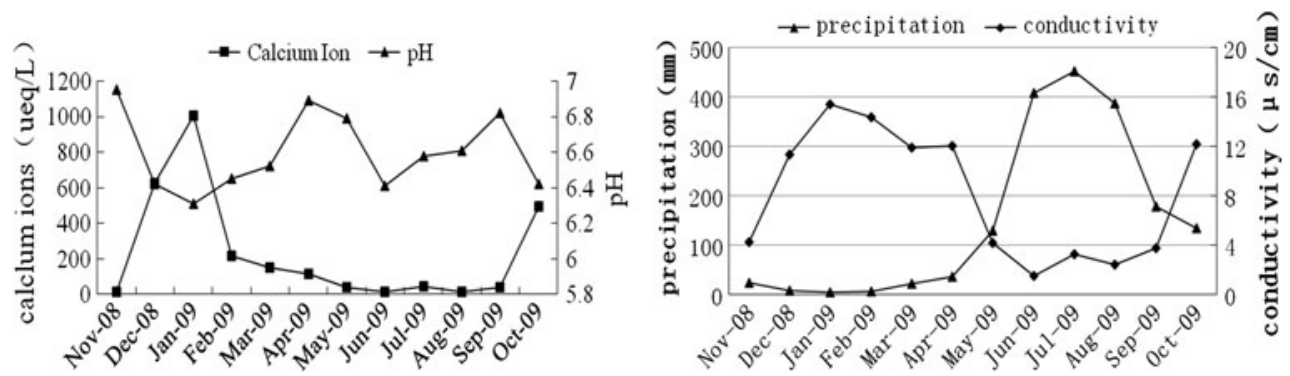

Fig. 2 Relation among $\mathrm{Ca}^{2+}$ and $\mathrm{pH}$; pH conductivity and precipitation from November 2008 to October 2009

mean value of $13.3 \mu \mathrm{eq} / \mathrm{L}$. All these different anions were ordered from high to low as $\mathrm{SO}_{4}{ }^{2-}>\mathrm{NO}_{3}{ }^{-}>\mathrm{Cl}^{-}>\mathrm{NO}_{2}{ }^{-}$. $\mathrm{Ca}^{2+}$ ranked first in the cation concentration with a mean $354.8 \mu \mathrm{eq} / \mathrm{L}$, followed by $\mathrm{Mg}^{2+}$. All of the different cations were ordered from high to low as $\mathrm{Ca}^{2+}>\mathrm{Mg}^{2+}>$ $\mathrm{NH}_{4}{ }^{+}>\mathrm{K}^{+}>\mathrm{Na}^{+}$. The concentration of ions decreased significantly from November to March in the following year except $\mathrm{Mg}^{2+}$ and $\mathrm{Ca}^{2+}$. In rainy season, the most abundant anions were $\mathrm{SO}_{4}{ }^{2-}$ and $\mathrm{NO}_{3}{ }^{-}$with the mean value of 29.51 and $7.11 \mu \mathrm{eq} / \mathrm{L}$, respectively, and the anions concentration had the same sequence in dry and rainy season. All the different cations were ordered from high to low as $\mathrm{Ca}^{2+}>\mathrm{Mg}^{2+}>\mathrm{K}^{+}>\mathrm{Na}^{+}>\mathrm{NH}_{4}^{+}$.

The ideal state of ion balance is: $\Sigma_{\text {cations }}=\Sigma_{\text {anions. }} . \Sigma_{\text {cat }}$ ions $=\left[\mathrm{Ca}^{2+}\right]+\left[\mathrm{Mg}^{2+}\right]+\left[\mathrm{Na}^{+}\right]+\left[\mathrm{K}^{+}\right]+\left[\mathrm{NH}_{4}^{+}\right]$, $\Sigma_{\text {anions }}=\left[\mathrm{SO}_{4}{ }^{2-}\right]+\left[\mathrm{NO}_{3}{ }^{-}\right]+\left[\mathrm{Cl}^{-}\right]+[\mathrm{X}]$, where $\mathrm{X}$ stands for other mild acid ion. The World Meteorological Organization employs the value of $\Sigma-/ \Sigma+$ as the evaluation metric of ion balance, if the value of $\Sigma-/ \Sigma+$ with the range of $1 \pm 0.2$, the ions were in balance, otherwise would be in imbalance (Wang 2002). The result of this study showed the cation concentration of fresh snow was 9.32 times as high as the anion concentration in dry season and 2.07 times in rainy season. Cation was excessive, which meant high concentration mild acid exited for ion balance. According to $\mathrm{Ku}-$ lshrestha et al.'s (2003) formula $\left[\mathrm{HCO}_{3}{ }^{-}\right]=10^{-11.2+\mathrm{pH}}$ $\left(5<\mathrm{pH}<7.5\right.$; assumes the $\mathrm{CO}_{2}$ balance in precipitation and atmospheric), the concentration of $\mathrm{HCO}_{3}{ }^{-}$was $25.70 \mu \mathrm{eq} / \mathrm{L}$ in dry season and $24.58 \mu \mathrm{eq} / \mathrm{L}$ in rainy season. There should be a certain amount of $\mathrm{CO}_{3}{ }^{2-}$ existing in the acidic environment, meanwhile gradient elution method showed there were micro formic acid in fresh snow without other organic acids, indicating that it was $\mathrm{HCO}_{3}{ }^{-}, \mathrm{CO}_{3}{ }^{-}$and micro formic acid maintained the balance with excess cation.

\section{Seasonal variation of major ions}

The chemical character of wet deposition changes with climate and environment. The chemical record of the snow can reflect the information of seasonal changes of climate and environment. It was evident that the concentration of inorganic ions was generally higher in the dry season than that in the rainy season, while the highest concentration occurred in pre-monsoon period (April-May; Fig. 3).

Back-trajectory analysis showed that the southeast and southwest monsoons brought excessive $\mathrm{Na}^{+}, \mathrm{Cl}^{-}, \mathrm{K}^{+}, \mathrm{NO}_{3}{ }^{-}$ and $\mathrm{SO}_{4}{ }^{2-}$ to Baishui Glacier No. 1 when they arrived during April-May (Fig. 4), which led to high concentrations of these ions in the fresh snow of the pre-monsoon season in particularly. The rainy season began from May in Yulong Mountain area and the leaching of precipitation led to lower ion concentration in the season compared with that in dry season. Ion concentration stayed at low levels during JuneOctober. In dry season, back-trajectory analysis showed that the ions of fresh snow in dry seasons mainly came from terrestrial under the influence of west wind circulation and the Plateau monsoon, and wind speed would reach its peak from December to February of the following year. The analysis also indicated that strong wind and the lack of rain in dry season brought a large number of dusts into the local atmosphere and existed for a long time in the form of aerosols. Moreover, terrestrial dust had been input into the study area constantly by the plateau monsoon and west wind circulation. In the process of the strong local atmospheric motion and vapor transpiration, a large number of weathered material from igneous or metamorphic rocks, such as feldspar, mica and other substances, got into atmosphere and then returned to the surface in the form of wet and dry deposition, which resulted in higher ion concentration of fresh snow in dry season (Kang et al. 2000; Pang et al. 2005).

\section{Discussion}

Ion correlation and different sources in the fresh snow

Correlation analysis suggested that the correlation of ions in dry season was stronger than that in rainy season (Table 2), indicating stronger consistency of ion source, chemical changes and migration in dry season. These ions correlated positively with precipitation and wind speed, but the correlation of ion and wind speed was weaker than the correlation of ion and precipitation in the dry season. Because there were less precipitation events in dry season 

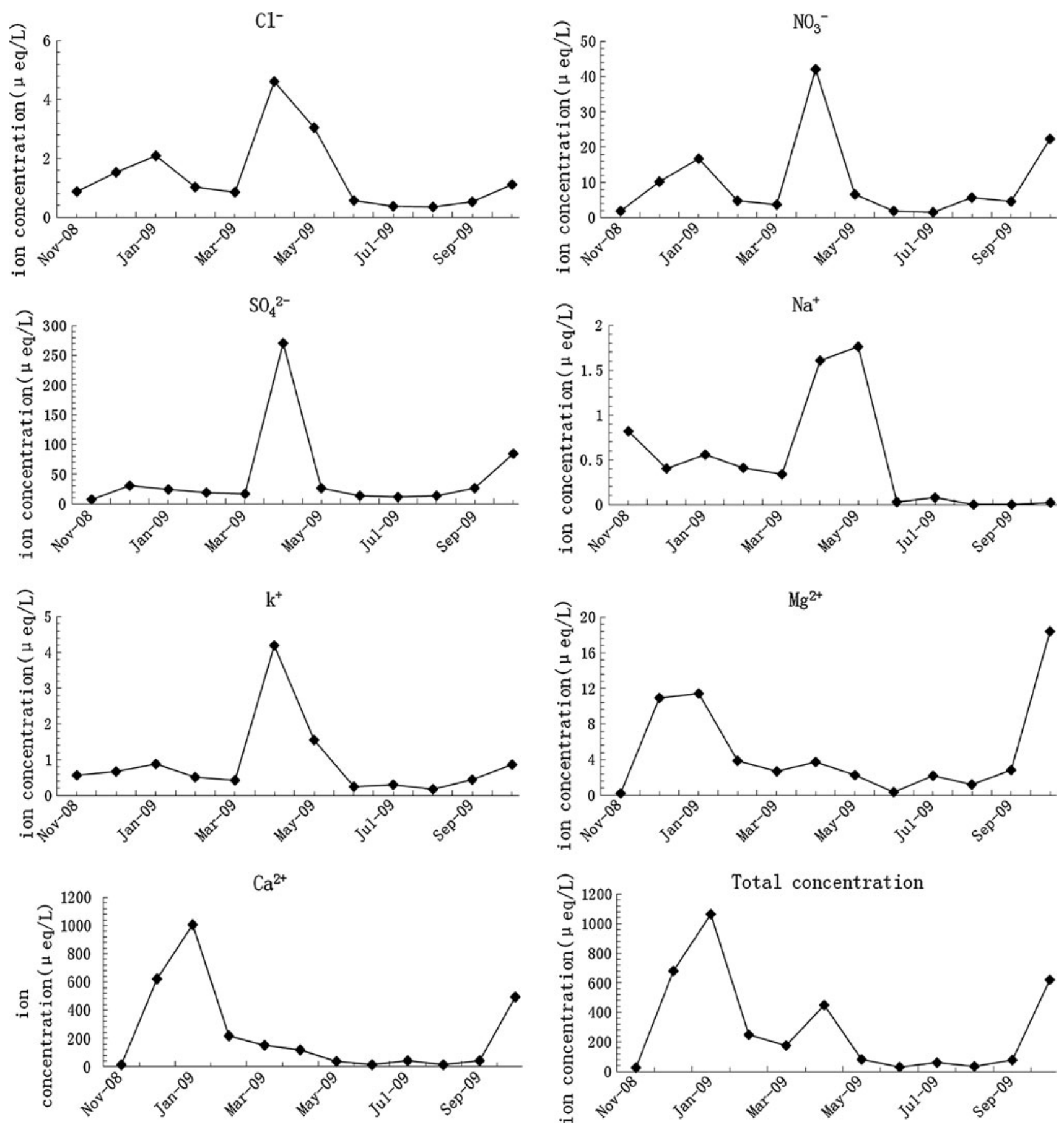

Fig. 3 Seasonal variation of major ions concentration

in Yulong Snow Mountain area, a large number of atmospheric aerosol can be attached to the water vapor and landing in the glacier surface. Significant positive correlation was observed among $\mathrm{Cl}^{-}, \mathrm{NO}_{3}{ }^{-}, \mathrm{SO}_{4}{ }^{2-}, \mathrm{NH}_{4}{ }^{+}$and $\mathrm{K}^{+} \quad(r>0.900, P<0.01)$ (Table 2), which had some connection with human activities (Chen 2006; Geng et al. 2007; Gao et al. 2008; Ju et al. 2008; Li et al. 2007; Xiao et al. 1993; Zhang et al. 2007, 2008). Significant positive correlation was observed between $\mathrm{NH}_{4}^{+}$and $\mathrm{K}^{+}$

( $r>0.900, P<0.01$ ) (Table 2), which greatly influenced by biomass burning and a variety of farmyard manure from agricultural activities surrounding the Yulong Mountain (Chen 2006; Gao et al. 2008; Zhao et al. 2008). The significant positive correlations between $\mathrm{NO}_{3}{ }^{-}$and $\mathrm{SO}_{4}{ }^{2-}(r>0.900, P<0.01)$ (Table 2$)$, which were mainly from the burning of fossil fuel, suggested their consistent source and form of existence (Ju et al. 2008; Li et al. 2007); $\mathrm{Na}^{+}$and $\mathrm{K}^{+}$, which were mainly contributed by igneous or 

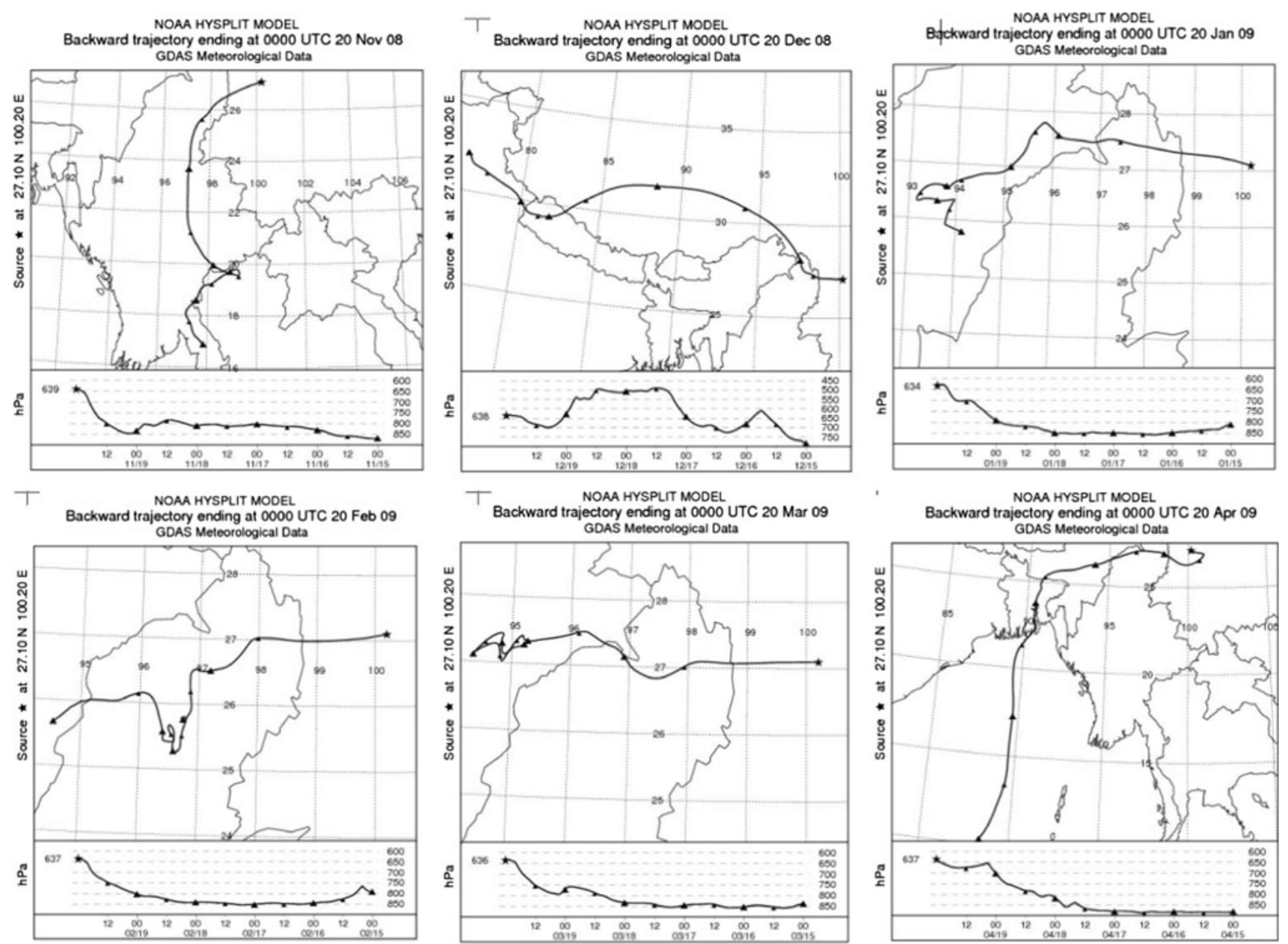

Fig. 4 The backward trajectories model in dry season at Yulong Mountain

Table 2 Correlation analysis of ions in dry season

\begin{tabular}{|c|c|c|c|c|c|c|c|c|c|c|c|}
\hline & $\mathrm{Cl}^{-}$ & $\mathrm{NO}_{2}^{-}$ & $\mathrm{NO}_{3}{ }^{-}$ & $\mathrm{SO}_{4}{ }^{2-}$ & $\mathrm{Na}^{+}$ & $\mathrm{NH}_{4}^{+}$ & $\mathrm{K}^{+}$ & $\mathrm{Mg}^{2+}$ & $\mathrm{Ca}^{2+}$ & Pre & Wind \\
\hline $\mathrm{Cl}^{-}$ & 1 & & & & & & & & & & \\
\hline $\mathrm{NO}_{2}^{-}$ & 0.180 & 1 & & & & & & & & & \\
\hline $\mathrm{NO}_{3}^{-}$ & $0.998 * *$ & 0.200 & 1 & & & & & & & & \\
\hline $\mathrm{SO}_{4}{ }^{2-}$ & $0.960 * *$ & 0.344 & $0.951 * *$ & 1 & & & & & & & \\
\hline $\mathrm{Na}^{+}$ & $0.893 *$ & -0.027 & $0.867 *$ & $0.912 *$ & 1 & & & & & & \\
\hline $\mathrm{NH}_{4}^{+}$ & $0.936 * *$ & 0.353 & $0.924 * *$ & $0.997 * *$ & $0.918 * *$ & 1 & & & & & \\
\hline $\mathrm{K}^{+}$ & $0.974 * *$ & 0.246 & $0.964 * *$ & $0.995^{* *}$ & $0.942 * *$ & $0.989 * *$ & 1 & & & & \\
\hline $\mathrm{Mg}^{2+}$ & 0.110 & -0.053 & 0.152 & -0.119 & -0.250 & -0.198 & -0.099 & 1 & & & \\
\hline $\mathrm{Ca}^{2+}$ & 0.019 & -0.314 & 0.058 & -0.247 & -0.293 & -0.325 & -0.205 & $0.946 * *$ & 1 & & \\
\hline Precipitation & 0.539 & 0.156 & 0.504 & 0.691 & 0.738 & 0.737 & 0.682 & -0.653 & -0.703 & 1 & \\
\hline Wind & 0.279 & 0.466 & 0.292 & 0.372 & 0.156 & 0.382 & 0.321 & -0.344 & -0.307 & 0.324 & 1 \\
\hline
\end{tabular}

** Correlation is significant at the 0.01 level (2-tailed), * correlation is significant at the 0.05 level (2-tailed)

metamorphic rocks, such as albite, feldspar and mica, had significant positive correlation $(r>0.900, P<0.01)$. It had been reported that part of $\mathrm{Cl}^{-}$originated from soil dust and salt lakes (Gao et al. 2008; Geng et al. 2007; Ju et al.
2008; Xiao et al. 1993). However, the correlation analysis showed that $\mathrm{Cl}^{-}$was not significantly related to $\mathrm{Mg}^{2+}$ and $\mathrm{Ca}^{2+}(r>0.900, P<0.01)$ (Table 2$)$, which originated from the soil dust and salt lakes partly, indicating that the 

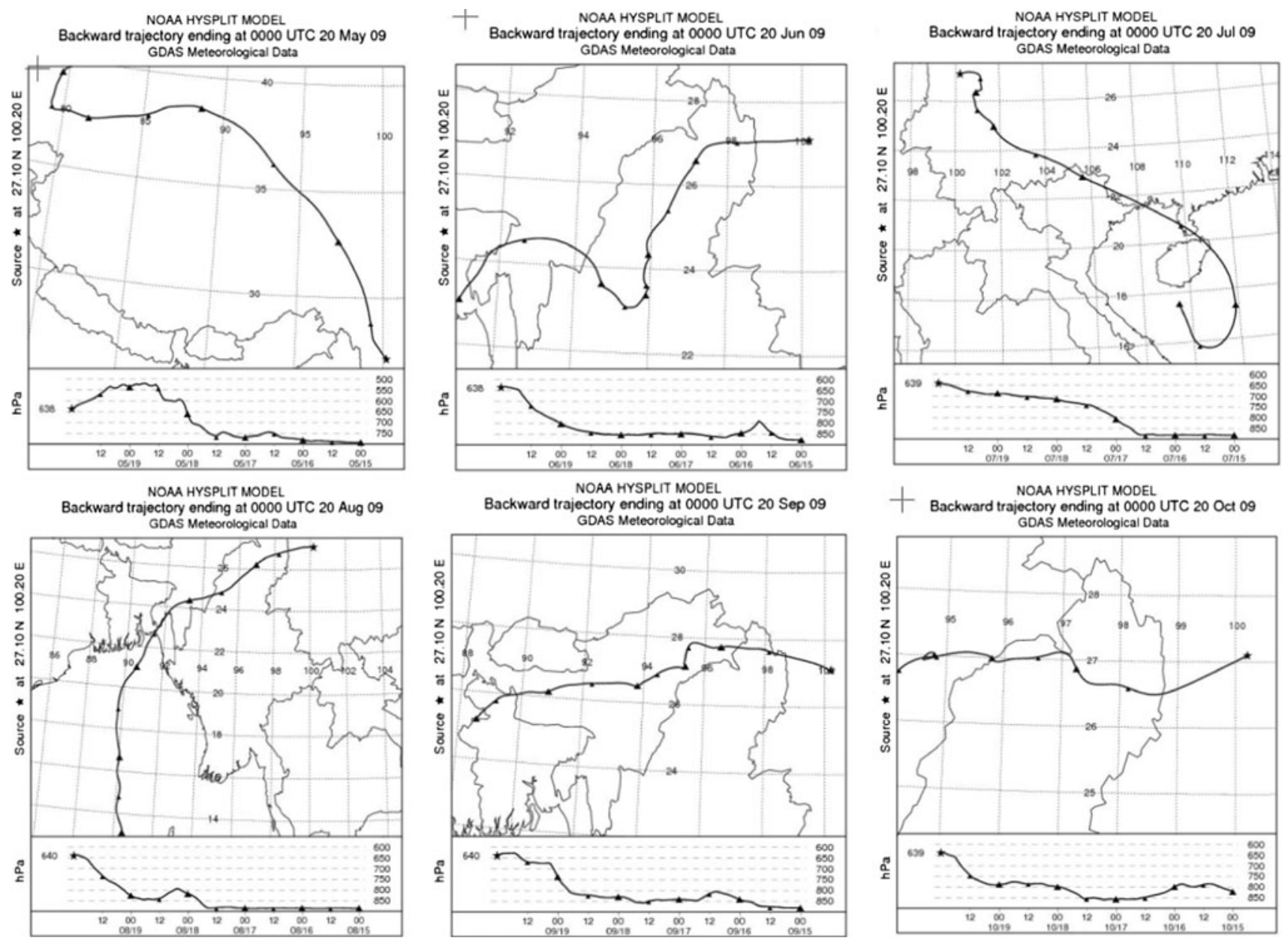

Fig. 5 The backward trajectories model in rainy season at Yulong Mountain

Table 3 Correlation analysis of ions in rainy season

\begin{tabular}{|c|c|c|c|c|c|c|c|c|c|c|c|}
\hline & $\mathrm{Cl}^{-}$ & $\mathrm{NO}_{2}^{-}$ & $\mathrm{NO}_{3}^{-}$ & $\mathrm{SO}_{4}^{2-}$ & $\mathrm{Na}^{+}$ & $\mathrm{NH}_{4}^{+}$ & $\mathrm{K}^{+}$ & $\mathrm{Mg}^{2+}$ & $\mathrm{Ca}^{2+}$ & Pre & Wind \\
\hline $\mathrm{Cl}^{-}$ & 1 & & & & & & & & & & \\
\hline $\mathrm{NO}_{2}^{-}$ & 0.417 & 1 & & & & & & & & & \\
\hline $\mathrm{NO}_{3}^{-}$ & 0.200 & 0.194 & 1 & & & & & & & & \\
\hline $\mathrm{SO}_{4}{ }^{2-}$ & 0.181 & 0.265 & $0.977 * *$ & 1 & & & & & & & \\
\hline $\mathrm{Na}^{+}$ & $0.962 * *$ & 0.337 & -0.048 & -0.075 & 1 & & & & & & \\
\hline $\mathrm{NH}_{4}^{+}$ & 0.674 & 0.143 & 0.653 & 0.698 & 0.495 & 1 & & & & & \\
\hline $\mathrm{K}^{+}$ & $0.963 * *$ & 0.410 & 0.395 & 0.401 & $0.876^{*}$ & $0.826^{*}$ & 1 & & & & \\
\hline $\mathrm{Mg}^{2+}$ & 0.067 & 0.287 & $0.966^{* *}$ & $0.984 * *$ & -0.178 & 0.570 & 0.288 & 1 & & & \\
\hline $\mathrm{Ca}^{2+}$ & 0.057 & 0.326 & $0.961 * *$ & $0.979 * *$ & -0.191 & 0.544 & 0.270 & $0.998 * *$ & 1 & & \\
\hline Precipitation & -0.635 & -0.008 & -0.636 & -0.669 & -0.473 & $-0.987 * *$ & -0.794 & -0.543 & -0.508 & 1 & \\
\hline Wind & $0.971 * *$ & 0.537 & 0.285 & 0.271 & $0.891 *$ & 0.675 & $0.936 * *$ & 0.158 & 0.162 & -0.604 & 1 \\
\hline
\end{tabular}

** Correlation is significant at the 0.01 level (2-tailed), * correlation is significant at the 0.05 level (2-tailed)

source of $\mathrm{Cl}^{-}$was more complex than others in dry season. $\mathrm{Mg}^{2+}$ and $\mathrm{Ca}^{2+}$ had significant positive correla$\operatorname{tion}(r>0.900, P<0.01)$ but had no significant correlation with other ions (Table 2). $\mathrm{Mg}^{2+}$ and $\mathrm{Ca}^{2+}$ were mainly contributed by weathered material of carbonate, evaporation of salts (e.g., gypsum) and alkaline earth metals (Gao et al. 2008; Geng et al. 2007; Ju et al. 2008; Xiao et al. 1993). 
Table 4 Principal component analysis of ions in dry season

\begin{tabular}{|c|c|c|c|c|c|c|c|}
\hline \multirow[t]{2}{*}{ Component } & \multicolumn{3}{|c|}{ Initial eigenvalues } & & \multicolumn{3}{|c|}{ Component } \\
\hline & Total & $\%$ of variance & Cumulative $\%$ & & 1 & 2 & 3 \\
\hline 1 & 5.855 & 65.053 & 65.053 & $\mathrm{Cl}^{-}$ & 0.964 & 0.261 & -0.028 \\
\hline 2 & 2.077 & 23.076 & 88.129 & $\mathrm{NO}_{2}^{-}$ & 0.281 & -0.248 & 0.927 \\
\hline 3 & 1.034 & 11.492 & 99.621 & $\mathrm{NO}_{3}^{-}$ & 0.953 & 0.297 & 0.007 \\
\hline 4 & 0.033 & 0.363 & 99.983 & $\mathrm{SO}_{4}{ }^{2-}$ & 0.998 & -0.002 & 0.068 \\
\hline 5 & 0.002 & 0.017 & 100.000 & $\mathrm{Na}^{+}$ & 0.937 & -0.061 & -0.329 \\
\hline 6 & $2.306 \mathrm{E}-16$ & $2.562 \mathrm{E}-15$ & 100.000 & $\mathrm{NH}_{4}^{+}$ & 0.995 & -0.083 & 0.057 \\
\hline 7 & $-6.547 \mathrm{E}-17$ & $-7.274 \mathrm{E}-16$ & 100.000 & $\mathrm{~K}^{+}$ & 0.999 & 0.041 & -0.027 \\
\hline 8 & $-1.887 \mathrm{E}-16$ & $-2.096 \mathrm{E}-15$ & 100.000 & $\mathrm{Mg}^{2+}$ & -0.133 & 0.956 & 0.238 \\
\hline 9 & $-5.046 \mathrm{E}-16$ & $-5.606 \mathrm{E}-15$ & 100.000 & $\mathrm{Ca}^{2+}$ & -0.245 & 0.966 & -0.007 \\
\hline
\end{tabular}

Table 5 Principal component analysis of ions in rainy season

\begin{tabular}{|c|c|c|c|c|c|c|}
\hline \multirow[t]{2}{*}{ Component } & \multicolumn{3}{|c|}{ Initial eigenvalues } & \multicolumn{3}{|c|}{ Component } \\
\hline & Total & $\%$ of variance & Cumulative $\%$ & & 1 & 2 \\
\hline 1 & 4.975 & 55.273 & 55.273 & $\mathrm{Cl}^{-}$ & 0.561 & 0.821 \\
\hline 2 & 2.958 & 32.871 & 88.144 & $\mathrm{NO}_{2}^{-}$ & 0.430 & 0.243 \\
\hline 3 & 0.908 & 10.092 & 98.236 & $\mathrm{NO}_{3}{ }^{-}$ & 0.897 & -0.393 \\
\hline 4 & 0.142 & 1.576 & 99.812 & $\mathrm{SO}_{4}{ }^{2-}$ & 0.914 & -0.402 \\
\hline 5 & 0.017 & 0.188 & 100.000 & $\mathrm{Na}^{+}$ & 0.332 & 0.933 \\
\hline 6 & $3.770 \mathrm{E}-16$ & $4.189 \mathrm{E}-15$ & 100.000 & $\mathrm{NH}_{4}{ }^{+}$ & 0.852 & 0.258 \\
\hline 7 & $2.176 \mathrm{E}-16$ & $2.418 \mathrm{E}-15$ & 100.000 & $\mathrm{~K}^{+}$ & 0.732 & 0.675 \\
\hline 8 & $-1.471 \mathrm{E}-16$ & $-1.635 \mathrm{E}-15$ & 100.000 & $\mathrm{Mg}^{2+}$ & 0.859 & -0.504 \\
\hline 9 & $-5.339 \mathrm{E}-16$ & $-5.932 \mathrm{E}-15$ & 100.000 & $\mathrm{Ca}^{2+}$ & 0.851 & -0.512 \\
\hline
\end{tabular}

Back-trajectory analysis showed that the southeast and southwest monsoons affected the area greatly while the effect of westerly monsoon circulation and plateau monsoon was very weak in rainy season (Fig. 5). The correlations among ions in rainy season were weaker than those in dry season (Tables 2, 3), indicating the ion source was more complex in rainy season. Because the water vapor of the study area was mainly originated from the ocean, and in the rainy season, precipitation accounted for $90 \%$ of the total annual precipitation ( $\mathrm{Li}$ and $\mathrm{Su}$ 1996). The results of sea-salt tracer showed that non-marine source mean ratio of $\mathrm{Cl}^{-}, \mathrm{SO}_{4}{ }^{2-}, \mathrm{Na}^{+}, \mathrm{K}^{+}, \mathrm{Mg}^{2+}$ and $\mathrm{Ca}^{2+}$ was $29.07,33.54$, $11.26,4.64,59.51$ and $79.43 \%$ in rainy season. Thus, it can be seen that the ions except $\mathrm{Mg}^{2+}$ and $\mathrm{Ca}^{2+}$ in rainy season at Baishui Glacier No. 1 mainly originated from the ocean. $\mathrm{Cl}^{-}$had positive correlations with $\mathrm{Na}^{+}$and $\mathrm{K}^{+}$in rainy season $(r>0.900, P<0.01)$ (Table 3$)$, which were sea-source. Significant positive correlation was observed among $\mathrm{NO}_{3}{ }^{-}$and $\mathrm{SO}_{4}{ }^{2-}$ in rainy season $(r>0.900$, $P<0.01$ ) (Table 3). The two ions mainly originated from local human activities of industries, transportation, etc. In addition, human industry activities should not be negligible in the areas where monsoon had passed (Li et al. 2007). All the ions negatively related with precipitation in rainy season (Table 3), led to low concentration of fresh snow by the continuous leaching of frequent precipitation in rainy season.

The main control factor of ion composition of fresh snow

In the dry season (Table 4), the first principal component was greatly influenced by $\mathrm{Cl}^{-}, \mathrm{NO}_{3}{ }^{-}, \mathrm{SO}_{4}{ }^{2-}, \mathrm{Na}^{+}, \mathrm{K}^{+}$and $\mathrm{NH}_{4}{ }^{+}$, and accumulative total of variance is $65.1 \%$, with $\mathrm{Cl}^{-}, \mathrm{NO}_{3}{ }^{-}, \mathrm{SO}_{4}{ }^{2-}$ and $\mathrm{NH}_{4}{ }^{+}$mainly from human activity in regions near the Yulong mountains, while $\mathrm{Na}^{+}$and $\mathrm{K}^{+}$ were from the bedrock. The second principal component is greatly influenced by $\mathrm{Mg}^{2+}$ and $\mathrm{Ca}^{2+}$, and accumulative total of variance is $23.076 \%$, with high-wind speed resulting in $\mathrm{Ca}^{2+}$ and $\mathrm{Mg}^{2+}$ ions in the surface snow by wet and dry deposition in dry season.

In the rainy season (Table 5), the first principal component was greatly influenced by $\mathrm{NO}_{3}{ }^{-}, \mathrm{SO}_{4}{ }^{2-}, \mathrm{NH}_{4}{ }^{+}$, $\mathrm{Mg}^{2+}, \mathrm{Ca}^{2+}$, and accumulative total of variance is $55.273 \%$; $\mathrm{NO}_{3}^{-}, \mathrm{SO}_{4}{ }^{2-}$ and $\mathrm{NH}_{4}{ }^{+}$came from the human industrial and agricultural activities, while $\mathrm{Mg}^{2+}$ and $\mathrm{Ca}^{2+}$ mainly originated from local bedrock of the area near Yulong mountain. The second principal component was 
greatly influenced by $\mathrm{Cl}^{-}, \mathrm{Na}^{+}, \mathrm{K}^{+}$, and the accumulative total of variance was $32.871 \%$, indicating that these species were mainly transported from oceans.

\section{Conclusions}

1. The $\mathrm{pH}$ of fresh snow was within the range of 6.27-7.01 and lower in rainy season because of continuous leaching of frequent precipitation. The conductivity in dry season was much higher than that in rainy season. 2. The concentration of inorganic ions was generally higher in dry season than that in rainy season. $\mathrm{Ca}^{2+}$ and $\mathrm{Mg}^{2+}$ reached its peak concentration from December to February of the following year, while the highest concentration of other ions occurred in pre-monsoon period (April-May).

3. The ions of fresh snow in dry seasons mainly came from terrestrial under the influence of west wind circulation and the Plateau monsoon. Southeast and southwest monsoons greatly affected the area in rainy season.

4. Bedrock composition, human activities and marine aerosol transport together with the water vapor were the principal inorganic ion sources of Baishui No. 1 Glacier.

Acknowledgments This study was supported by a Project of the National Natural Science Foundation of China (40971019) and a West Light Foundation of China's Academy of Sciences (O828A11001). The authors gratefully acknowledge the NOAA Air Resources Laboratory for the provision of the HYSPLIT transport and dispersion model and/or READY website (http://www.arl.noaa.gov/ready.html) used in this publication.

Open Access This article is distributed under the terms of the Creative Commons Attribution License which permits any use, distribution, and reproduction in any medium, provided the original author(s) and the source are credited.

\section{References}

Barrie LA, Fisher D, Koerner RM (1985) Twentieth century trends in Arctic air pollution revealed by conductivity and acidity observations in snow and ice in the Canadian high Arctic. Atmos Environ 19(12):2055-2063

Chen Z (2006) Liquid environmental science. Science Press, Beijing

Gao T, Kang S, Zhang Q (2008) Major ionic features and their sources in the Nam Co Basin over the Tibetan Plateau. Environ Sci 29(11):3009-3016

Geng Z, Hou S, Zhang D (2007) Major ions in ice cores and snow pits from the Yulong Mountain Temporal and spatial variations and their sources. J Glaciol Geol 29(2):192-200

Hammer CU (1980) Acidity of polar ice cores in relation to absolute dating, past volcanism and radio-echoes. J Glaciol 25(93): 359-372

He Y, Yao T, Cheng C (2001a) Climatic records in a firn core from an Alpine temperate glacier on Mt. Yulong, southeastern part of the Tibetan Plateau. Episodes 24(1):13-18
He Y, Yao T, Cheng G (2001b) Preliminary analysis of climatic and environmental signals of a shallow ice-core from a Chinese temperate glacier on Mt Yulong. J Lanzhou Univ (Nat Sci) 37(4):118-124

He Y, Theakstone WH, Yao T (2002a) The irregular pattern of isotopic and ionic signals in the typical monsoon temperateglacier area, Yulong Mountain, China. Ann Glaciol 135:167-174

He Y, Yao T, Theakstone WH (2002b) Recent climatic significance of chemical signals in a shallow firn core from an alpine glacier in the South-Asia monsoon region. J Asian Earth Sci 20(3): 289-296

He Y, Zhang Z, Theakstone WH (2003) Changing features of the climate and glaciers in China's monsoonal temperate glacier region. J Geophys Res 108(D17):4530

Hempel L, Thyssen F, Gundestrup N (2000) A comparison of radioecho sounding data and electrical conductivity of the GRIP ice core. J Glaciol 46(154):369-374

Hu M, Zhang J, Wu Z (2005) Beijing Chemical compositions of precipitation and its role in the removal of atmospheric particles. Sci China 35(2):169-176

Ju J, Zhu L, Wang Y (2008) Composition spatial distribution and environmental significance of water ions in Lake Pumoyun and its catchments, Southern Tibet. J Lake Sci 20(5):591-599

Kahl JDW, Martinez DA, Kuhns H (1997) Air mass trajectories to Summit, Greenland: a 44-year climatology and some episodic events. J Geophys Res 102(C12):26861-26875

Kang S, Qin D, Yao T (2000) A study on precipitation chemistry in the late summer in the northern slope of Mt. Xixabangma. Acta Sci Circumst 20(5):574-578

Kulshrestha UC, Monika J, Kulshlrestha RS (2003) Chemical characteristics of rainwater at an urban site of south-central India. Atmos Environ 37(21):3019-3026

Li J, Su Z (1996) Glaciers of Hengduan Mountains. Science Press, Beijing

Li Z, He Y, Pang H (2007) Source of major anions and cations of snowpacks in the typical monsoonal temperate glacial region of China. Acta Geogr Sin 62(9):992-1001

Li Z, He Y, Pang H (2008a) Source of major anions and cations of snowpacks in Hailuogou No. 1 Glacier, Mt Yulong, China. J Geogr Sci 18(1):115-125

Li Z, He Y, Yuan L (2008b) Chemical characteristic on major ions of rain water in LiJiang city. Environ Chem 27(5):648-652

Li Z, He Y, Pang H (2009) Chemistry of snow deposited during the summer monsoon and in the winter season at Baishui glacier No. 1, Yulong Mountain, China. J Glaciol 55:190

Mayewski PA (1986) Snow chemistry from Xixabangma Peak, Tibet. J Glaciol 33:542-543

Pang H, He Y, Zhang Z (2005) Origin of summer monsoon rainfall identified by $\delta 180$ in precipitation. Chin Sci Bull 50(23): 2761-2764

Pang H, He Y, Theakstone WH (2007) Soluble ionic and oxygen isotopic compositions of a shallow firn profile, Baishui glacier No. 1, southeastern Tibetan Plateau. Ann Glaciol 46:325-330

Raben P, Theakstone WH, Kjetil T (2000) Relations between winter climate and ionic variations in a seven-meter deep snowpack at Okstindan. Norway. Arct Antarct Alp Res 32(2):189-196

Stravisi F, Verza GP, Tartari G (1998) Meteorology and climatology at high altitude in Himalaya. In: Baudo R, Tartari G, Munawar $M$ (eds) Top of the world environmental research: Mount Everest-Himalayan Ecosystem, Ecovision World Monograph Series. Backhuys, Leiden

Taylor KC, Hammer CU, Alley RB (1993) Electrical conductivity measurements from the GISP2 and GRIP Greenland ice cores. Nature 366:549-552

Theakstone WH (2008) Dating stratigraphic variations of ions and oxygen isotopes in a high-altitude snowpack by comparison with 
daily variations of precipitation chemistry at a low-altitude site. Hydrol Res 39(2):101-112

Thompson LG, Yao T, Thompson ME (2000a) A high-resolution millennial record of the South Asian monsoon from Himalayan ice cores. Science 289:1916-1919

Thompson LG, Thompson EM, Henderson AK (2000b) Ice-core palaeoclimate records in tropical South America since the Last Glacial Maximum. J Quat Sci 15(4):377-394

Wake CP, Mayewski PA, Xie Z (1993) Regional variation of monsoon and desert dust signals record in Asian glaciers. Geophys Res Lett 20:1411-1414

Wake CP, Dibb JE, Mayewski PA (1994) The chemical composition of aerosols over eastern Himalaya and Tibetan Plateau during low dust periods. Atmos Environ 28:695-704

Wang Y (2002) The standards manual of air pollution to influence forests of sampling, assessment, monitoring and analysis methods. China Technology and Science Press, Beijing
Wolff EW, Moore JC, Clausen HB (1995) Long-term changes in the acid and salt concentrations of the GRIP Greenland ice core from electrical stratigraphy. J Geophys Res 100:16249-16264

Xiao H, Sheng Z, Huang M (1993) The chemical characteristics of precipitation in Western Pacific tropical areas. Acta Sci Circumst 13(2):143-148

Zhang M, Wang S, Hong B (2007) Analysis of atmospheric precipitation a case study of Jinhua City of Zhejiang Province. Environ Chem 26(5):699-703

Zhao D, Xiong J, Xu Y (1985) Chemical characteristics of acid rain in China. Environ Chemistry Special Issue (March):137-146

Zhao H, Yao T, Xu B (2008) The change of $\mathrm{NH}_{4}{ }^{+}$concentration over the past century in Mushitage ice core. Chin Sci Bull 53(7):815-820

Zhou G, Tian D, Yang L (2009) Chemical composition of precipitation and its marine source at Liuxihe of Guangzhou. Acta Ecol Sin 29(9):4924-4933 